\title{
Economic Origins of the Partitions ${ }^{1}$
}

The underlying causes of the partitions of Poland have, as we know, been discussed in abundant works, yet they have not arrived at a consensus. The most intensely debated matter is the question of the internal and external causes of the collapse of Poland. The most extreme theory concerning the internal origins of the downfall of the erstwhile Commonwealth was formulated in the well-known sentence by Bobrzyński, who asserted that "neither the boundaries nor the neighbours, but internal disorder drove us into loss of political existence."2 The most extreme counterclaim came from Balzer, who opposed this theory vehemently, stating that "the view according to which the deficiencies of our system were allegedly the major cause of the decline of Poland proved erroneous," as "the actual, decisive reason behind the collapse of our statehood, the crucial causa efficiens of that event is the covetousness of

1 Translated from: J. Rutkowski, Gospodarcze podłoże rozbiorów Polski, “Ruch Prawniczy, Ekonomiczny i Socjologiczny” 1930, 1, pp. 236-245 by Szymon Nowak and proofread by Stephen Dersley. The translation and proofreading were financed by the Ministry of Science and Higher Education under 848/2/P-DUN/2018. This paper is an abridged version of the lecture given in Poznań in 1926. In view of the limited space, half of the original text and all notes had to be removed. I hope that despite those deletions the essential course of the disquisition has not lost its clarity. As far as circumstances allow, I shall substantiate the views expressed here more extensively elsewhere, in particular those which at first glance may appear insufficiently supported due to the aforesaid deletions.

2 M. Bobrzyński, Dzieje Polski w zarysie II, Kraków 1890, p. 348. 
the united and therefore superiorly potent neighbours, who conspired to bring about the doom of Poland."3

The first of the views cited above would suggest that the direct cause of the annihilation of the Polish state was not the incursion of external foes, but an internal breakdown that the neighbours readily exploited. Meanwhile, the arrangement of social and state structures-not only under Stanisław August when it witnessed thorough reorganization and revival, but also in the Saxon period - managed quite satisfactorily, given the times, to meet the needs of the society with respect to safety, the judiciary and other internal affairs of the state.

Admittedly, certain destructive forces were there, particularly in the East, but confronted with the strength of the State they were so weak that in themselves they would not have brought about its collapse. The Bar Confederation cannot be considered such an internal breakdown, since confederations against the Crown had been formed quite often well over a century prior to the first partition. They had weakened the state structure, but did not led to its collapse.

The partitions of the Commonwealth are first and foremost a page in the diplomatic history of the states which participated in it, and a page in the history of the armed forces of those states which enforced the occupation. The entire deliberations on the causes of Poland's collapse should set out from the facts which are "external" to its history and constitute the direct cause behind the downfall of the old Commonwealth.

This does not mean, however, that the "covetousness of conspiring neighbours" is a sufficient explanation for the catastrophe, and that Poland's internal system was not one of the key contributing factors of the partitions. The state organization of the Commonwealth in the eighteenth century was strong enough to fulfil the internal tasks with respect to its own society, but too weak to withstand the external pressure.

The military weakness of the Commonwealth is indubitably the direct internal cause of its collapse. As is known, the military strengths of 
Poland and the neighbouring states were greatly disproportionate. From 1717 until the first partition, the Crown and the Lithuanian forces had merely several thousand men all told. What could such a small army do against the vast numbers of the Austrian, Prussian and Russian armies? Therefore, conducting the partitions, especially the first one, was an undertaking which entailed no risk from the military standpoint. The Commonwealth was in a situation which virtually provoked the neighbour to invade and partition a country which carelessly ignored the fact that its frontiers were in no way secured.

Even the greatest physical and material effort on the Polish part would not have availed given an analogous effort made by the three neighbours, but one can hardly presume that in the eighteenth century those states would have embarked on partitions and that the undertaking would have been executed consistently and successfully if it had required great sacrifices, and above all, whether they would have agreed on uniform diplomatic and military action precisely at a moment when they confronted no hindrance from other states in Europe.

In a variety of ways, Poland's military weakness is directly and indirectly associated with the democratic political system of the Nobles' Commonwealth. One of the incentives to keep the numbers of the standing army so low, particularly in the Saxon period, was that the Sejm (national diet) feared that the king would use the armed forces to introduce absolute monarchy, such as those which had long been established or were just emerging at the time among the near and more remote neighbours of Poland. Particularly during the reign of August II, who would return so often to the idea of imposing absolute monarchical rule, even at the expense of the partial partition of the Commonwealth, those fears were not without some serious foundations.

However, following the death of that king the concerns subsided, and under August III the augmentation of the army was discussed at the Sejm on numerous occasions. However, until the first partition no serious measures were implemented, again due to internal-political rea- 
sons. With the in-fighting between the magnate houses which at the time held Poland's fates in their hands, there were fears that - should the circumstances change-a larger army may boost the political significance of the opponents, therefore no decisive steps were taken. At any rate, the efforts made during the reign of August III did not reach the stage where the financial difficulties involved would have become evident and, having penetrated into the minds of the political circles, presented a real obstacle to building up the army.

After the first partition, and in particular during the Four-Year Sejm, the appreciation of military situation considerably increased. Awareness of the necessity of having a large army as a foundation of an independent political entity became more widespread, but new difficulties arose when the idea was to be pursued in practice, which became evident in the weakness of the treasury.

Issues of a financial nature had become immediately apparent as early as 1775 , when one began to consider enlarging the army - to the very modest number of 30,000 men for the time being-in more specific terms. With the planned military reform in mind, the preliminary revenue envisaged at the beginning of the Four-Year Sejm was 18,000,000, but since only 13,500,000 was collected, the military budget had to be reduced from 12,000,000 to 6,000,000. By enacting a "perpetual contribution" as a financial mainstay of the army, it was hoped that the tax would yield 35,000,000. However, only 9,000,000 was effectively levied. Conducting income assessments on a different basis, a special tax adjustment committee increased that revenue to 14,500,000, which was still below half of what had been envisaged. It was therefore necessary to revise the plan for an army of 100,000 soldiers. By virtue of an enactment, the strength of the army was reduced to 65,000 but even that could not be accomplished. When Russia declared war on Poland in May 1792 and invaded its territory with two armies of 100,000 men, the Commonwealth had merely 56,000 people under arms, but not all of them could be fielded. 
The weakness of the Polish exchequer at this time, which hindered the creation of an army that would have been strong enough to face the challenges of those times, is linked to the political organization of the Commonwealth on the one hand, and its economic system on the other. Absolute monarchs can more readily and promptly decide to impose high taxes on their subjects then diets can on their voters. On the other hand, the rulers of Austria and Prussia found it much easier to exact money from the countries they had subjugated than was possible with respect to Poland, whose economic constitution was much feebler.

Poland's economic weakness was particularly evident in industrial production, trade, and credit framework -in short in the economic organization of its towns and cities. Admittedly, Russia's economic system was not more developed or stronger than Poland's, but when comparing economic relationships in Poland and Russia from the standpoint of the ability to raise a strong military structure, we must not forget about the differences in population. A lower tax burden levied on a greater population enabled Russia to create a larger military force than was possible in Poland, where a relatively substantial portion of the social revenue went to the state.

As for the causes of the Commonwealth's economic weakness, one should in the first place mention the very numerous hostile incursions which had ravaged the country so much since the mid-seventeenth century. However, it would be entirely erroneous to presume that the Commonwealth owed its economic deficiencies in the eighteenth century solely to the devastations of war. There was another factor which adversely affected the economic system and its reconstruction after the ruinous wars: the economic policies adopted by the Sejm and regional assemblies (sejmik), which were subsequently enforced by the administrative authorities.

The Sejm and sejmik were institutions where the class interests of great estate owners were furthered. The differences boiled down to greater or lesser short-sightedness of the policies or contradictory eco- 
nomic positions adopted among the nobles themselves. On the one hand, there were the disparate interests of the magnates and the lower nobility or gentry (szlachta), and the equally incongruent interests of agrarian groups from different provinces across the Commonwealth.

Within the legislative bodies, the economic programme aiming to concentrate the largest possible portion of the social revenue in the hands of the great landowners encountered no opposition. It was only the shortage of an adequately robust administration that caused the policies to be less far-reaching than envisioned in theory and legislation.

The policies yielded short-term and thoroughly tangible outcomes. It enabled great landowners to enjoy a standard of living which, given the defeats and ravages that the country had suffered, would have been impossible if the development of economic relationships had relied on the free competition of particular strata of the society. Nevertheless, the high living standard-in relation to the overall production capacity at the time-available to owners of large estates came at a cost, weakening the economy of the Commonwealth across various domains: agriculture, industry, trade and taxation.

Peasant serfdom was the chief manifestation of the agrarian policies espoused by the nobility, enabling great landowners to effect a complete economic restructuring of their estates. The peasantry of the fourteenth and fifteenth century had in fact been minor independent agricultural producers and constituted the majority of the rural population of Poland, but over time they were converted into labourers at manorial farms, as serfs or hired labour force. The interest of the manorial farms became the chief factor shaping relationships in agriculture.

The impact of serfdom on economic relationships on was evinced most vividly and directly in the era of serfdom. Without bondage, or attachment to land whilst retaining peasants' rights to it, without the omnipotence of the unappealable patrimonial jurisdiction, without the subjects being unable to bring action against their lord in Crown courts, the economy based on manorial demesnes and corvée would not have 
developed. In tenant villages serfdom was felt as well. The rents agreed under a voluntary contract were usually lower than the compulsory rents decreed for bonded peasants. This may be demonstrated by comparing fixed rents with the rates for the voluntary, mostly one-year leases that as a rule amounted to less than the usual dues of the same villages. Also, foreign peasants who took land under a contract paid lower rents than the Polish rural population who had lived there for centuries. The servitude was there not only in the duties one was supposed to pay, but also when gainful work was undertaken. Those hired compulsorily would receive less substantial remuneration than labourers hired on a free basis.

This constant increase of the obligatory burden of labour inevitably resulted in the diminishing economic independence of the peasant population; the farmland they held was split into smaller plots while the number of small-holders and landless grew: zagrodnicy (who owned a house and farm buildings), chałupnicy (owned only a cottage) and komornicy (who had to rent a room in a farmhouse). This gradually diminishing economic independence meant that revenue from land estates soared, whereas the former prosperity of the peasants dwindled.

Experience teaches us that reducing the share of agricultural workers in the yield of their labour, once it exceeds a certain limit, will have an adverse effect on production, causing it to deteriorate. Rather than with hired labourers, this occurs relatively faster with the serfs who are entrusted with the draught animals and farm equipment to cultivate the fields of their landlord. Agricultural production had been on the decline since the seventeenth century, especially since the latter half, so that agriculture in the eighteenth century was in a worse state than it had been in the sixteenth. Eighteenth-century authors attribute this decline mainly to serfdom, but there can be no doubt that the military defeats sustained in the mid-seventeenth and early eighteenth century played a role.

After all, the reduction of the area of arable land which corresponded to the sparsity of population owing to warfare and the epidemics which followed cannot be imputed to serfdom alone. However, the latter 
factor did contribute to the lower birth rates among the peasants caused by their poverty.

It is more difficult to account for the decreased productivity of the grain and soil. The phenomenon may been resulted from the poorer quality of cultivation and agricultural technology in general, reflecting a shortage of financial resources due to wartime destruction and the diminishing efficiency of serfdom-based work.

As for the industrial policy in the sixteenth and seventeenth century, one should invariably distinguish between the policies pursued by the rulers and those supported by the Sejm and regional sejmiki. The monarch would often attempt to introduce new types of industry, especially where the branches catering to the refined needs of the upper classes were concerned. Meanwhile, fixing prices for ready-made craft products or craft work were the most important matters debated at the diets and local assemblies. From the perspective of the class interests of agricultural producers, striving for the lowest possible prices is perfectly understandable, as the income from their estates would enable them to purchase more industrial-made goods and enjoy a higher standard of living.

As a result of the financial relationships at the time, there was a general tendency for the products-agricultural and industrial alike-to grow more expensive. The dominant policy was to curb the increases in price of the latter, which it sought to achieve by two means: through a liberal customs policy and by dictating prices for craft work and craft products, which were determined in voivodeship-level tariffs.

Although municipal authorities intervened to some extent where the rates were concerned, the policy is quite correctly considered a manifestation of the designs and goals of the nobility. Opinions are divided as to whether the policy was effective. There can be no doubt, however, that it failed to stop the price increases, although one should not-in my opinion - draw the conclusion that a policy of fixed rates is utterly ineffectual. It operated jointly with and in the same direction as the customs 
policy, therefore studying the outcomes of either policy separately is severely limited. At any rate, it is doubtless that in conjunction they managed to slow down the increases of prices for craft labour and craft products. Price growth rate in that area was considerably lower than in the case of rural products.

The consequences this entailed were very significant indeed. The nobles were able - ceteris paribus - to purchase more and more industrial products, in other words to elevate their standard of living or, at the time of the calamities of war and universal impoverishment, they did not need to reduce that standard as much as they would have had to if that price policy had not operated. If, by and large, a peasant was not able to do likewise, it was due solely to the increasing duties that nullified the positive effect which the price policy might have had for the peasant estate. The nobles benefited even more, deriving both the aforementioned direct as well as indirect advantages from the policy. The cost of it all was borne by the town-dweller, the craftsman in particular, who had to content himself with constantly diminishing earnings from his work. This compelled him to reduce his standard of living and prevented any progress in industrial production, which the impoverished craftsmen simply could not afford. This may also explain why the attempts to introduce the capitalist system in the field of industry seldom originated with the particular producers or merchant-bourgeois. It was the land-owning estate, magnates in particular, who played a key role here. It was a class that had much more substantial capital at its disposal which could be invested in industrial enterprises.

We may now return to the question of whether the treasury ailed because the economic system was weak or whether the potential of the latter was insufficiently exploited; alternatively, what role was played by each of those factors. It is obvious that the Polish economy, conspicuously weaker than the economies of our Western neighbours, prevented our treasury from becoming as affluent as theirs. However, the fact that treasury legislation-even during the period of the Four-Year Sejm, when the revenue was raised to unprecedented amounts-did not 
exhaust all possibilities, becomes evident upon comparing the history of the Polish exchequer in the final years of the Commonwealth with history of the same in the early years following the partitions. The very substantial increase of that revenue had already been noted by Staszic. Under duress, we were able to afford to maintain the armed forces of the partitioning states, yet we could not afford to make voluntary contributions to keep an army capable of defending the independence of the Commonwealth.

That phenomenon is strictly linked to the centuries-long tradition of treasury policy and legislation. During the reign of Kazimierz Jagiellończyk, a watershed period for both treasury and military history, when a regular army instead of a levy en masse became the chief instrument of waging war, the nobles had to contribute a portion of their income towards the regular forces, unless they took part in the war themselves. The concept of a tax being an equivalent of military service is clearly highlighted in a number of conscription universals from the first half of the sixteenth century, especially in their provisions regarding the gentry.

However, thanks to their political consequence, the nobility at the time, i.e. at the turn of the modern era, gained fiscal freedom. Towards the end of the fifteenth century they were exempted from customs duties, while direct taxation became less and less important in the early sixteenth century, only to cease after 1521.

The fiscal freedom of the nobility endured until the first partition. It was only sporadically interrupted in the latter half of the seventeenth century and three quarters of the following century by several enactments introducing capitation and general customs tax. This was the terrible tragedy of the development of our state- that great landowners, having seized control of public affairs, directed economic policies in a way that delivered a vast portion of the revenue into their hands, at the expense of the townspeople and peasants. At the same time, they were unwilling to surrender an adequate part of that income which 
would go towards defence of the state, and thus indirectly their security as well.

The tax statutes enacted under Stanisław August placed an incomparably greater fiscal burden on the landowning class. This applied in particular to the general customs tax, vastly increased quarter tax and the perpetual contribution. Very serious results thus ensued. When the resolutions of the Four-Year Sejm had been promulgated, the revenue of the Commonwealth's Crown treasury from a territory diminished by the first partition was six times larger than the analogous revenue in the Saxon era. It was a major effort, yet it was still too modest to save the state from the partitions. That the effort could have been more substantial was demonstrated by the Prussian tax policy after the collapse of the Commonwealth. Had its economy been stronger, had it not been exhausted by the wars and fatigued by the economic policies described above, fiscal legislation, which entered into force thanks to the endeavours of the Four-Year Sejm, would have yielded even more revenue, sufficient to build an army exceeding even 100,000 men. However, given the economic situation at the time, there was a need for laws that would have imposed even higher levy on the income from the great estates for the benefit of the State, but the representatives of the landowning class of whom the Four-Year Sejm was composed could not bring themselves to do so.

Our reasoning so far has reached a point where the various internal causes behind the decline of the Commonwealth become combined and form an inextricable nexus. The weak economy itself does not account for the collapse and cannot be considered its sole cause, as it would not have prevented the creation of a strong fiscal apparatus and a strong army, if a tax policy suited to the political circumstances had existed. The latter could have been introduced by an absolute ruler or Sejm whose members had higher standards of public morality and a greater capacity to sacrifice the interests of the estate they represented for the sake of the common good than was actually the case. 
The political system of the Commonwealth, with its omnipotent assembly of the nobles would not have been detrimental if the economy had been stronger, or if at critical moments its members had demonstrated a higher spiritual level.

The moral condition of the then community of nobles, which cannot be considered to have been inferior to the condition of the nobility in other countries who at each turn displayed the same economic inclinations, would not have contributed to the collapse if the rights of the nobility had been limited, that is, if its overwhelming influence had already been undermined by absolute monarchy.

It was only the concerted working of those three factors: economic deficiency, the political system, and the morals of the ruling estate, that constituted-as an integral whole-the internal cause of the partitions. Even so, all that taken together would not have been a sufficient reason, had it not been for the collusion of external factors, meaning the rapacity of the neighbours.

Thus, we arrive at the conclusion that neither external nor internal causes considered separately permit one to resolve why the partitions happened, just as none of the internal factors alone cannot be deemed to have been critically decisive. Only when combined into an entirety can they offer an explanation for the political disaster of the Commonwealth.

\section{Literature}

Balzer O., Z zagadnień ustrojowych Polski, Lwów 1916. Bobrzyński M., Dzieje Polski w zarysie II, Kraków 1890. 